\title{
In vivo migration of labeled autologous natural killer cells to liver metastases in patients with colon carcinoma
}

\author{
Lina Matera*1, Alessandra Galetto2 ${ }^{2}$, Marilena Bello4, Cinzia Baiocco , \\ Isabella Chiappino5 ${ }^{5}$ Giancarlo Castellano ${ }^{4}$, Alessandra Stacchini ${ }^{6}$, \\ Maria A Satolli ${ }^{3}$, Michele Mele ${ }^{7}$, Sergio Sandrucci ${ }^{8}$, Antonio Mussa ${ }^{8}$, \\ Gianni Bisi ${ }^{4}$ and Theresa L Whiteside ${ }^{9}$
}

\begin{abstract}
Address: ${ }^{1}$ Dept. of Internal Medicine, University of Turin, Italy, ${ }^{2}$ University of East Piedmont "Amedeo Avogadro", Novara, Italy, ${ }^{3}$ Dept. of Biological and Clinical Science, S. Luigi's Hospital, Orbassano, Italy, ${ }^{4}$ S.C.D.U. of Nuclear Medicine 2, Molinette Hospital, Turin, Italy, ${ }^{5} \mathrm{Medical}$ Oncolocy, COES, Molinette Hospital, Turin, Italy, ${ }^{6}$ Flow Cytometry Unit, Laboratory of Pathology, Molinette Hospital, Turin, Italy, ${ }^{7}$ Dept of Surgical and Medical Disciplines, University of Turin, Italy, ${ }^{8}$ S.C.D.U. of Surgical Oncology, University of Turin, Italy and ${ }^{9}$ University of Pittsburgh Cancer Institute, Pittsburgh, PA, USA

Email: Lina Matera* - lina.matera@unito.it; Alessandra Galetto - alegaletto@yahoo.it; Marilena Bello - mbello@molinette.piemonte.it; Cinzia Baiocco - baiocco@yahoo.it; Isabella Chiappino - chiappino@molinette.piemonte.it;

Giancarlo Castellano - gcastellano@molinette.piemonte.it; Alessandra Stacchini - astacchini@molinette.piemonte.it;

Maria A Satolli - mariaantonietta.satolli@unito.it; Michele Mele - michele.mele@unito.it; Sergio Sandrucci - sergio.sandrucci@unito.it;

Antonio Mussa - antonio.mussa@unito.it; Gianni Bisi - gianni.bisi@unito.it; Theresa L Whiteside -whitesidetl@upmc.edu

* Corresponding author
\end{abstract}

Published: I4 November 2006

Journal of Translational Medicine 2006, 4:49 doi:I0.1 186/1479-5876-4-49
Received: 18 April 2006

Accepted: 14 November 2006

This article is available from: http://www.translational-medicine.com/content/4/I/49

(C) 2006 Matera et al; licensee BioMed Central Ltd.

This is an Open Access article distributed under the terms of the Creative Commons Attribution License (http://creativecommons.org/licenses/by/2.0), which permits unrestricted use, distribution, and reproduction in any medium, provided the original work is properly cited.

\begin{abstract}
Background: Besides being the effectors of native anti-tumor cytotoxicity, NK cells participate in Tlymphocyte responses by promoting the maturation of dendritic cells (DC). Adherent NK (A-NK) cells constitute a subset of IL-2-stimulated NK cells which show increased expression of integrins and the ability to adhere to solid surface and to migrate, infiltrate, and destroy cancer. A critical issue in therapy of metastatic disease is the optimization of NK cell migration to tumor tissues and their persistence therein. This study compares localization to liver metastases of autologous A-NK cells administered via the systemic (intravenous, i.v.) versus locoregional (intraarterial, i.a.) routes.
\end{abstract}

Patients and methods: A-NK cells expanded ex-vivo with IL-2 and labeled with II'In-oxine were injected i.a. in the liver of three colon carcinoma patients. After 30 days, each patient had a new preparation of II'In-A-NK cells injected i.v. Migration of these cells to various organs was evaluated by SPET and their differential localization to normal and neoplastic liver was demonstrated after i.v. injection of ${ }^{99 \mathrm{mT}} \mathrm{T}$ phytate.

Results: A-NK cells expressed a donor-dependent CD56 ${ }^{+} \mathrm{CD} \mathrm{I6}{ }^{+} \mathrm{CD} 3-(\mathrm{NK})$ or $\mathrm{CD} 56^{+} \mathrm{CD} / 6^{+} \mathrm{CD} 3^{+}$ (NKT) phenotype. When injected i.v., these cells localized to the lung before being visible in the spleen and liver. By contrast, localization of i.a. injected A-NK cells was virtually confined to the spleen and liver. Binding of A-NK cells to liver neoplastic tissues was observed only after i.a. injections.

Conclusion: This unique study design demonstrates that A-NK cells adoptively transferred to the liver via the intraarterial route have preferential access and substantial accumulation to the tumor site. 


\section{Background}

Effector functions mediated by cells of the immune system are thought to play a crucial role in the control of tumor development and progression. However, it has been difficult to distinguish the part played by individual immune cell subsets in these processes. T cells that mediate tumor-specific responses are generally considered to be the major anti-tumor effectors. However, cells responsible for mediating innate or natural immunity have been recently recognized to also contribute to anti-tumor defense. Extensive investigation of tumor growth and metastasis in animal models suggests that NK cells are early participants in the immune response and are particularly effective in eliminating blood-borne metastases $[1,2]$. In contrast, $\mathrm{T}$ cells are the effector cells responsible for specific, long-lasting immunity.

In addition to their direct anti-tumor functions [3-7], NK cells can mobilize adaptive immune response [8] presumably by promoting the maturation of dendritic cells (DC) [9-14] and by providing them with antigenic material derived from tumor cell lysis $[15,16]$. DC mediate both protective and autoimmune responses, depending on their maturational state and soluble factors present in the tissue microenvironment $[17,18]$. In the liver, for example, Kupffer cells and LSEC constitutively express the antiinflammatory cytokines, IL-10 and transforming growth factor beta (TGF- $\beta$ ), while hepatocytes secrete IL-10 in response to autocrine and paracrine TGF- $\beta$. These cytokines could inhibit maturation of liver DC $[19,20]$. Therefore, delivery of NK cells to the liver milieu could shift the balance from tolerogenic to immunogenic conditions. The hypothesis we are entertaining is that NK cellmediated DC maturation in the liver could alter the suppressive local environment, enhance immune responses, and lead to the elimination of tumor cells metastasizing to the liver.

The efficacy of adoptive immunotherapy of solid tumors depends on the localization of therapeutic cells to tissues. This in turn is influenced by the route of administration and access of the cells to tumor. Liver metastases are solely fed by the hepatic artery, and injection of chemotherapeutic agents [21] and immune cells [22] via this route has proven to be effective in controlling the spread of tumors of the digestive tract, whose initial metastasis site is the liver.
The success of adoptive immunotherapy is also critically dependent on the migratory properties of the effector cells and their ability to access tumor cells in situ. High expression levels of molecules belonging to the integrin and to the human-leukocyte-function-associated antigen families, namely LFA-1 and very late antigen (VLA)-4, which interact with adhesion molecules on the tumor endothelium, is a characteristic feature of activated NK cells [23]. NK cells have the ability to migrate to, infiltrate and kill cancer cells in solid tumor tissues [24,25] and eliminate established tumors and metastases. Based on their selective ability to rapidly ( $1-5 \mathrm{~h}$ ) respond to $22 \mathrm{nM}$ IL-2 by a temporal adherence to solid surface, we have previously defined subpopulations of NK cells, namely activated ANK cells, which constitute $4-30 \%$ of fresh peripheral blood NK cells and are notably different from the nonadherent IL-2 activated cells (NA-NK). A-NK cells produce significant levels of the DC-maturating cytokines IFN- $\gamma$, IL1- $\beta$ and TNF- $\alpha$ and display potent anti-tumor activities in vivo and in vitro [26].

Injection of A-NK cells into the hepatic artery may be an ideal approach to treating tumors metastasizing to the liver. Although this approach to therapy has been previously used, no formal evidence exists for the superior tumor infiltrating capacity of intraarterially (i.a.)-delivered versus intravenously (i.v.)-delivered A-NK cells. Here we compare in the same patient the efficiency of tumor localization of ex vivo generated clinical grade A-NK cells delivered via locoregional i.a. versus i.v. injections.

\section{Patients, materials and methods Protocol design and patient's characteristics}

Three patients with colon carcinoma metastasizing to the liver only were enrolled in this study, which was approved by the Italian Ministry of Health and by the Ethical Committee of Turin Molinette's Hospital and the Piedmont Region. Informed consent was obtained from all patients. The patients' characteristics and previous therapy are listed in Table 1. For delivery of A-NK cells, the hepaticarterialcatheter implanted for chemotherapeutical purposes was used. At the time of A-NK-cell injection, all patients had discontinued chemotherapy for at least one month. No disease progression had occurred between the first (i.a.) and the second (i.v.) A-NK administration. Patients had $160 \mathrm{ml}$ blood drawn twice for each of two A-NK cell preparations.

Table I: Patients' characteristics

\begin{tabular}{|c|c|c|c|c|}
\hline Patient & Sex/Age & Pathology & Site of metastasis & Previous treatment \\
\hline I & $M / 57$ & Colon carcinoma & Liver & 5FU/FUTR \\
\hline 2 & $M / 62$ & Colon carcinoma & Liver & 5FU/FUTR \\
\hline 3 & $M / 60$ & Colon carcinoma & Liver & 5FU/FUTR \\
\hline
\end{tabular}




\section{A-NK cell generation}

Cells were generated for therapy under conditions conforming to current good manufacturing practice (GMP), i.e., using animal-free serum components and reagents approved for human therapy and accompanied by certificates of analysis (COA). PBMC were isolated from venous blood by Ficoll-Hypaque (Lymphoprep, $1.077 \mathrm{~g} / \mathrm{ml}$; Nycomed Pharma, Oslo, Norway) gradient centrifugation and washed in RPMI 1640 (Gibco cat. No. 61870-028) containing $1 \%(\mathrm{v} / \mathrm{v})$ defibrinated autologous plasma (DAP). The PBMC were suspended at the concentration of $1 \times 10^{7}$ cells $/ \mathrm{ml}$ in RPMI 1640 containing 10\% DAP, 100 $\mathrm{U} / \mathrm{ml}$ penicillin, $2 \mathrm{mM}$ L-glutamine, $3 \mathrm{mg} / \mathrm{ml}$ sodium bicarbonate, Pen/strep $(100 \mathrm{U} / \mathrm{ml})$ (culture medium) and $5 \mathrm{mM}$ phenylalanine methyl ester (PME) at 7.0-7.2 pH. Following a $30 \mathrm{~min}$ incubation at RT to deplete monocytes, cells were extensively washed in medium, counted and suspended in the adherence medium supplemented with $1 \mathrm{mM} \mathrm{CaCl}_{2}, 1 \mathrm{mM} \mathrm{MgCl} 2,100 \mathrm{U} / \mathrm{ml}$ heparin and $6,000 \mathrm{IU} / \mathrm{ml}$ of rIL-2 (Chiron s.r.l., Siena, Italy), obtained from the local Molinette's Hospital Pharmacy and designated for human use. After $3 \mathrm{~h}$ at $37^{\circ} \mathrm{C}$ in a $5 \% \mathrm{CO}_{2}$ atmosphere non-adherent cells were removed by washing (x3) with pre-warmed medium, and adherent cells (A-NK cell precursors) were counted in four sample flasks with a grid bottom and multiplied for the total number of culture flasks. A feeder layer consisting of rIL-2 (50 IU/ml)stimulated monocyte-depleted PBMC irradiated at 5,000 rads suspended in culture medium containing $1 \times 10^{6} / \mathrm{ml}$ of Con A $(10 \mu \mathrm{g} / \mathrm{ml})$ and $6,000 \mathrm{IU} / \mathrm{ml}$ rIL-2 was added to each flask. Cells were incubated for 15 days and were fed every four days with rIL-2 $(6,000 \mathrm{IU} / \mathrm{ml})$ culture medium to adjust cell density to $1.5 \times 10^{6} / \mathrm{ml}$.

\section{A-NK cell labeling and administration}

A-NK cells were harvested, washed, counted and their phenotype was determined. An aliquot was sent for sterility analysis. The remaining cells were suspended in $20 \mathrm{ml}$ clinical grade $0.93 \% \mathrm{NaCl}$ solution containing $25 \% \mathrm{DAP}$, $6,000 \mathrm{IU} / \mathrm{ml}$ rIL-2 and $37 \mathrm{MBq}{ }^{111} \mathrm{In}$-oxine (Altana Pharma, Milan, Italy). A-NK cells were generated twice for each patient and the same number of cells was labeled on both occasions. After $15 \mathrm{~min}$ at room temperature cells were washed twice in $0.93 \% \mathrm{NaCl}$ saline containing $25 \%$ DAP and 6,000 IU/ml rIL-2. The cell pellet was then suspended in $10 \mathrm{ml} 0.93 \% \mathrm{NaCl}$ containing $20 \%$ human albumin (clinical grade) and cells were injected i.a. After 30 days, A-NK cells were again administered, this time i.v. Paracetamol(Acetaminophen) (Perfalgan, UPSA Lab, Braine-l'Alleud, Belgium) $(1 \mathrm{~g})$ and $1 \times 10^{7} \mathrm{rIL}-2$ were given s.c. $30 \mathrm{~h}$ before and $48 \mathrm{~h}$ after these injections. Each patient was injected with the same number of labeled cells, generated in separate cultures at each of the two time points.

\section{Evaluation of labeling efficiency}

Labeling efficiency was defined as the ratio between free and cell-bound tracer, evaluated in a gamma counter as the cpm of radioactivity contained in the washing supernatant and in the cell pellet.

\section{A-NK cell migration evaluation}

Planar whole-body and single-photon emission-computed tomography (SPET) acquisitions were performed by two-head gamma camera (VARICAM-ESCINT, General Electric, Milwankee, WI, USA) equipped with "medium energy" collimators for ${ }^{111} \mathrm{In}$, with $20 \%$ window and energy peaks at 173 and $247 \mathrm{KeV}$. Planar whole-body acquisitions were performed at 1,6,24,72 and $96 \mathrm{~h}$ and SPET acquisitions at 6 and $96 \mathrm{~h}$.

\section{Localization of A-NK cells to liver metastases}

To estimate the extent of the non-pathological liver parenchyma, patients were given an i.v. injection of $99 \mathrm{mTc}$ Phytate (FITATEC) (AMERSHAM SORIN, Saluggia, Italy) before A-NK cell administration. Liver images were acquired after $10 \mathrm{~min}$ by the gamma camera equipped with "low energy" collimator with $20 \%$ window and energy peak at $140 \mathrm{KeV} .{ }^{111}$ In labeled A-NK images were acquired by the gamma camera equipped with "medium energy" collimators, as described above.

\section{Phenotypic analysis of A-NK cells}

A-NK cells were analyzed by flow cytometry on day fifteen. One million cells were incubated for $20 \mathrm{~min}$ at $4{ }^{\circ} \mathrm{C}$ with mouse anti-human simultest CD3FITC/ CD16.CD56PE or with $\gamma_{1}$ FITC $/ \gamma_{2 a}$ PE isotype controls (Becton Dickinson, San Jose, CA, USA). Flow cytometric analysis was performed using a FACScan flow cytometer CellQuest (v2.1q) software (Becton Dickinson).

\section{Results \\ Growth and phenotypic characteristics of A-NK cells}

In two cultures of A-NK cells generated for every patient, very similar numbers of adherent cells were obtained. However, the number of A-NK cells that expanded after fifteen days of culture were strikingly different in the same patient (Table 2). Phenotyping of the final products showed a patient-specific prevalence of NKT $\mathrm{CD} 16^{+} \mathrm{CD}_{56} 6^{+} \mathrm{CD}^{+}$(patient \#1) or of $\mathrm{NK}$ CD $16{ }^{+} \mathrm{CD} 56^{+} \mathrm{CD} 3-$ (patients \#2 and \#3) cells. This phenotype was observed early in culture and persisted throughout the culture period (not shown).

\section{NA-NK cell labeling efficiency and stability}

The mean efficiency of labeling was 56\% (range 42-67\%) (Table 2). 
Table 2: Biological characteristics of injected A-NK

\begin{tabular}{|c|c|c|c|c|c|c|c|c|c|c|}
\hline Patient. & $\begin{array}{l}\text { Injection } \\
\text { Site }\end{array}$ & Blood $\mathrm{ml}$ & PBMCI & $\begin{array}{l}\text { Monocyte- } \\
\text { depleted }\end{array}$ & $\begin{array}{l}\text { Adherent } \\
\text { cells }^{2}\end{array}$ & $\begin{array}{c}\text { Final A-LAK } \\
\text { recovery }^{3}\end{array}$ & $\begin{array}{c}\text { CDI6+CD5 } \\
6^{+} \text {CD3 }^{+} \%\end{array}$ & $\begin{array}{c}\text { CDI6+CD5 } \\
6^{+} \text {CD3 } \%\end{array}$ & $\begin{array}{l}\text { Labeled }^{4} \text { cells/ } \\
\text { injection }\end{array}$ & $\begin{array}{l}\text { Labeling } \\
\text { efficiency }\end{array}$ \\
\hline \multirow[t]{2}{*}{1} & i.a. & 160 & $1.2 \times 10^{8}$ & $8 \times 10^{7}$ & $6 \times 10^{6}$ & $5 \times 10^{8}$ & 56 & 13 & $5 \times 10^{8}$ & 58 \\
\hline & i.v. & 160 & $2.8 \times 10^{8}$ & $1.5 \times 10^{8}$ & $5 \times 10^{6}$ & $1.2 \times 10^{9}$ & 59 & 14 & $5 \times 10^{8}$ & 56 \\
\hline \multirow[t]{2}{*}{2} & i.a. & 160 & $1.2 \times 10^{8}$ & $8 \times 10^{7}$ & $3.2 \times 10^{6}$ & $1.6 \times 10^{9}$ & 12 & 69 & $5 \times 10^{8}$ & 62 \\
\hline & i.v. & 160 & $2.5 \times 10^{8}$ & $9 \times 10^{7}$ & $3.6 \times 10^{6}$ & $6 \times 10^{8}$ & 2 & 85 & $5 \times 10^{8}$ & 67 \\
\hline \multirow[t]{2}{*}{3} & i.a. & 160 & $1.3 \times 10^{8}$ & $5 \times 10^{7}$ & $1 \times 10^{6}$ & $6 \times 10^{8}$ & 10 & 60 & $5 \times 10^{8}$ & 55 \\
\hline & i.v. & 160 & $1.3 \times 10^{8}$ & $8 \times 10^{7}$ & $5 \times 10^{6}$ & $2.3 \times 10^{9}$ & 12 & 69 & $5 \times 10^{8}$ & 42 \\
\hline
\end{tabular}

I Peripheral blood mononuclear cells (PBMC) and monocyte-depleted populations were obtained from blood as described in Material and Methods. ${ }^{2}$ Cells obtained after incubation of monocyte-depleted cells in presence of the adhrence medium (Materials and Methods).

3 Number of A-NK cells recovered after fifteen days of cultures of adherent cells with rIL-2 and feeder cells as described in Materials and Methods.

${ }^{4}$ A-LAK cells recovered on day fifteen were ajusted at the indicated number and labeled with 11 IIn-oxine before being injected i.a. or i.v.

\section{Migration of A-NK cells to the liver}

Migration of the i.a. injected A-NK cells and of i.v. injected A-NK cells (after 30 days) were assessed by planar wholebody scintigraphy and SPET. Fig. 1 shows the kinetics of tracer accumulation after i.a. (A) and i.v. (B) injection in the three patients. Very low tracer activity was observed in the lung after i.a. injection, whereas liver labeling was immediate (four-fold and two-fold the lung and spleen labeling respectively) and was still evident at $96 \mathrm{~h}$. Immediate labeling of lung observed after i.v. injection became evident at $24 \mathrm{~h}$ and declined thereafter. The representative radioimaging of Fig. 2 illustrates differential progression of ${ }^{111}$ In-labeled A-NK cells from lung to spleen to liver during the observation time after i.a. (A) and i.v. (B) delivery (patient \#2). In a $24 \mathrm{~h}$ axial section from this patient, SPET showed preferential accumulation of radioactivity in liver compared to spleen six hours after i.a. (Fig. 3A), but not after i.v. (Fig. 3B).

\section{Localization of A-NK cells to tumor nodules}

${ }^{99 \mathrm{mTC}}$ phytate is transformed by chelation with serum calcium in vivo into a microcolloid which is taken up by cells of the reticulo-endothelial system, particularly Kupffer cells. ${ }^{99 m T c}$ phytate was given i.v. before A-NK cell delivery to estimate the extent of normal liver parenchyma. ${ }^{111}$ In radioactivity was then evaluated in $99 \mathrm{mTc}$ phytate-positive and in $99 \mathrm{mTc}$ phytate-negative areas to assess the ratio between tumor-involved and normal tissues. This ratio was $>3$ for i.a., but remained virtually unchanged at 0.7 for i.v. (Fig. 4, mean \pm SE of the values referred to the three patients). A representative SPET image analysis performed in patient \# 1 (Fig. 5) illustrates ${ }^{99 m}$ Tc phytate uptake (top) and ${ }^{111}$ In radioactivity (bottom) after i.a. (Fig. 5A) or i.v. (Fig. 5B) cell delivery. The $99 \mathrm{~m}$ Tc phytate-negative (cold) areas identified by the arrows in Figs. 5A and 5B (top) are positive for ${ }^{111}$ In in Fig. 5A (bottom), but not in Fig. 5B (bottom). The image is consistent with the localization of ${ }^{111}$ In-labeled A-NK cells in the neoplastic hepatic nodule after i.a., but not after i.v. administration.

\section{Discussion}

As the first metastatic site of gastric and colon cancer, the liver is a critical check point for systemic disease progression. The liver is rich in immune cells, including DC precursors, NK cells and T lymphocytes. Generation of CD8 ${ }^{+}$ tumor-specific $\mathrm{T}$ cells, which mediate anti-tumor responses in the liver, is enhanced by activated NK cells, which facilitate maturation of DC [8-14]. However, a suppressive liver environment hampers functional maturation of DC and the consequent activation of the adaptive immune response. Therapy with activated NK cells can therefore be envisaged as a means to breaking liver tolerance and to boosting antigen-specific anti-tumor responses. The efficiency of adoptive cellular immunotherapy of cancer strongly depends on the type, number and the route of delivery of effector cells that are expected to reach malignant tissues after their transfer.

We demonstrate that ex vivo expanded A-NK cells efficiently home to liver metastases and only accumulate therein, when they gain direct access to the portal system. This route may favor the localization and concentration of immune effector cells in the tumor, since liver metastases are fed with arterial blood. However, preferential localization in the tumor is also likely to depend on the intrinsic homing characteristics of the injected cells. NK cells have a regulated expression of a number of integrins that may play a role in their localization. In situ immunohistochemical staining has shown NK-cell localization to the red pulp of the spleen and the sinusoid regions of the liver. Few NK cells are present in other solid organs and, surprisingly, there are relatively few NK cells in lymph nodes [27]. NK cells present in the liver sinusoids are strategically located to detect and kill arriving metastatic cancer cells, and their accumulation at this site is favored by chemokine ligands present in the LSEC [28]. The LSEC cytokine environment, with IL-2 produced by resident T cells [29] and IL-15 and IL-12 produced by Kupffer cells [30], might be expected to potentiate homing and cyto- 


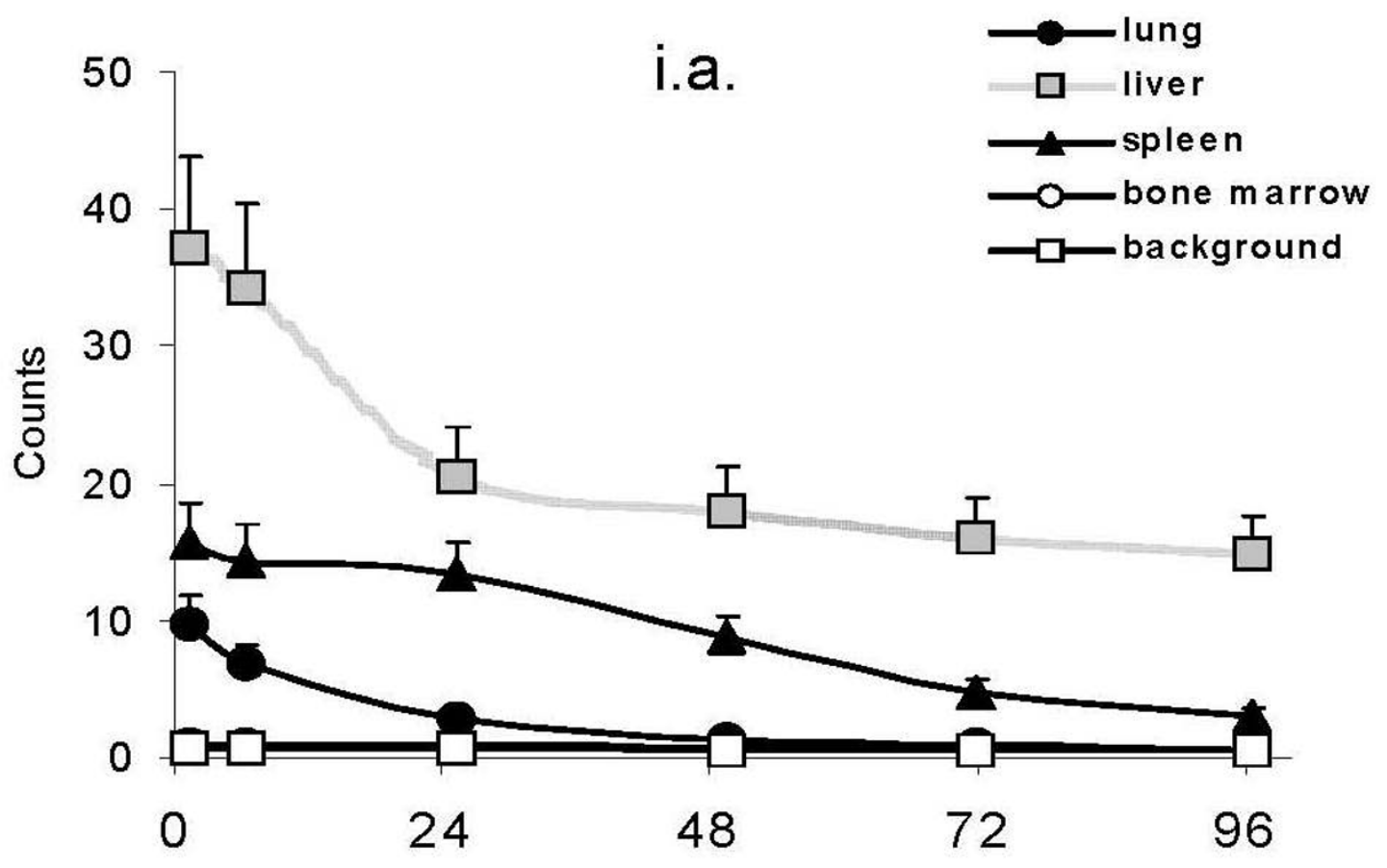

\section{hours}

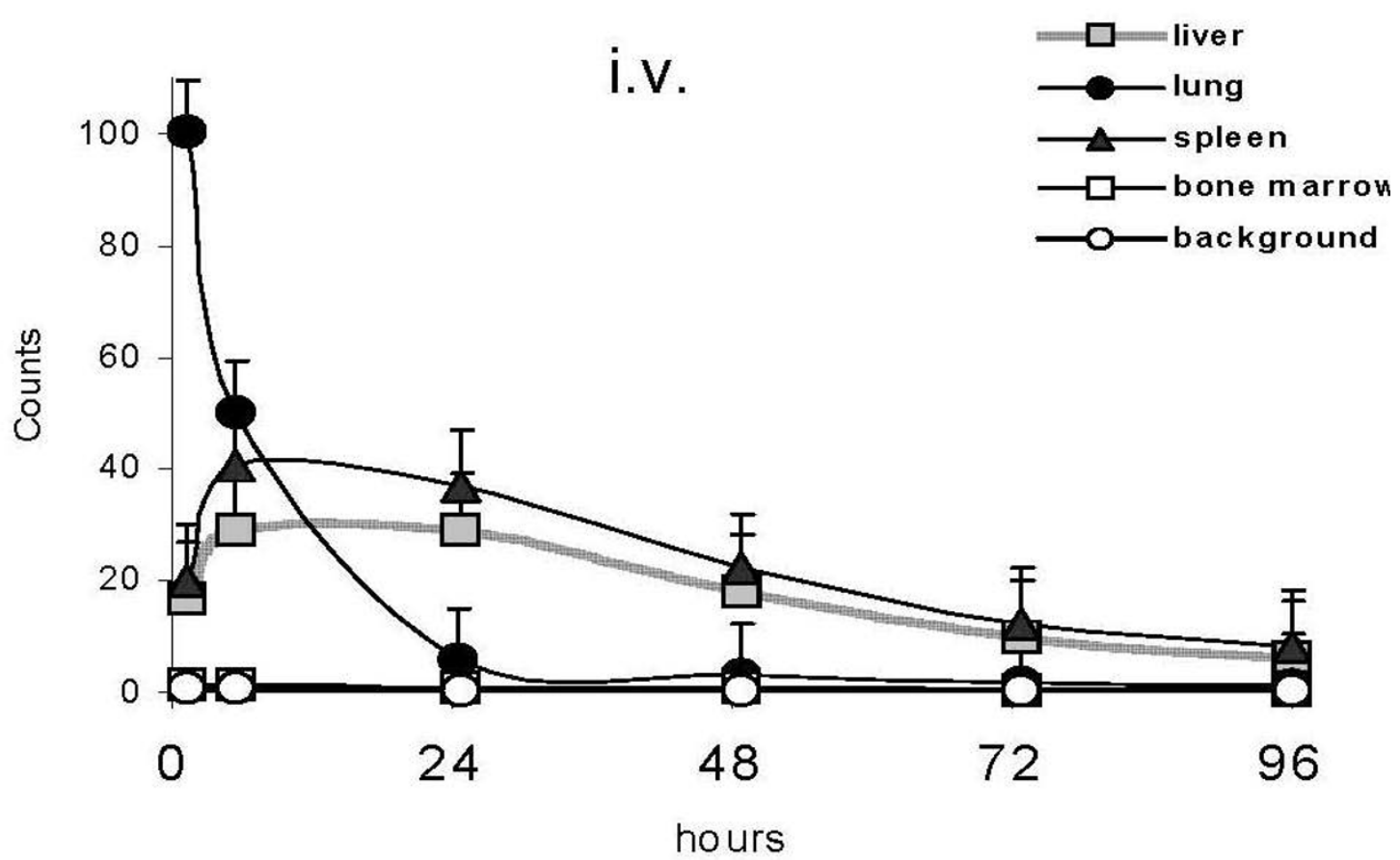

Figure I

In vivo migration of A-NK cells. The same number of 1 ' In-labeled A-NK cells were injected i.a. (A) and, after one month, i.v. (B). Organ distribution of radioactivity was monitored at the indicated times ( $\mathrm{X}$ axis) by planar whole-body acquisition ( $\mathrm{Y}$ axis). An earlier and greater migration of labeled cells was observed in the liver after i.a. administration. Counts are corrected for isotope decay and refer to the mean \pm SE of the three patients. 

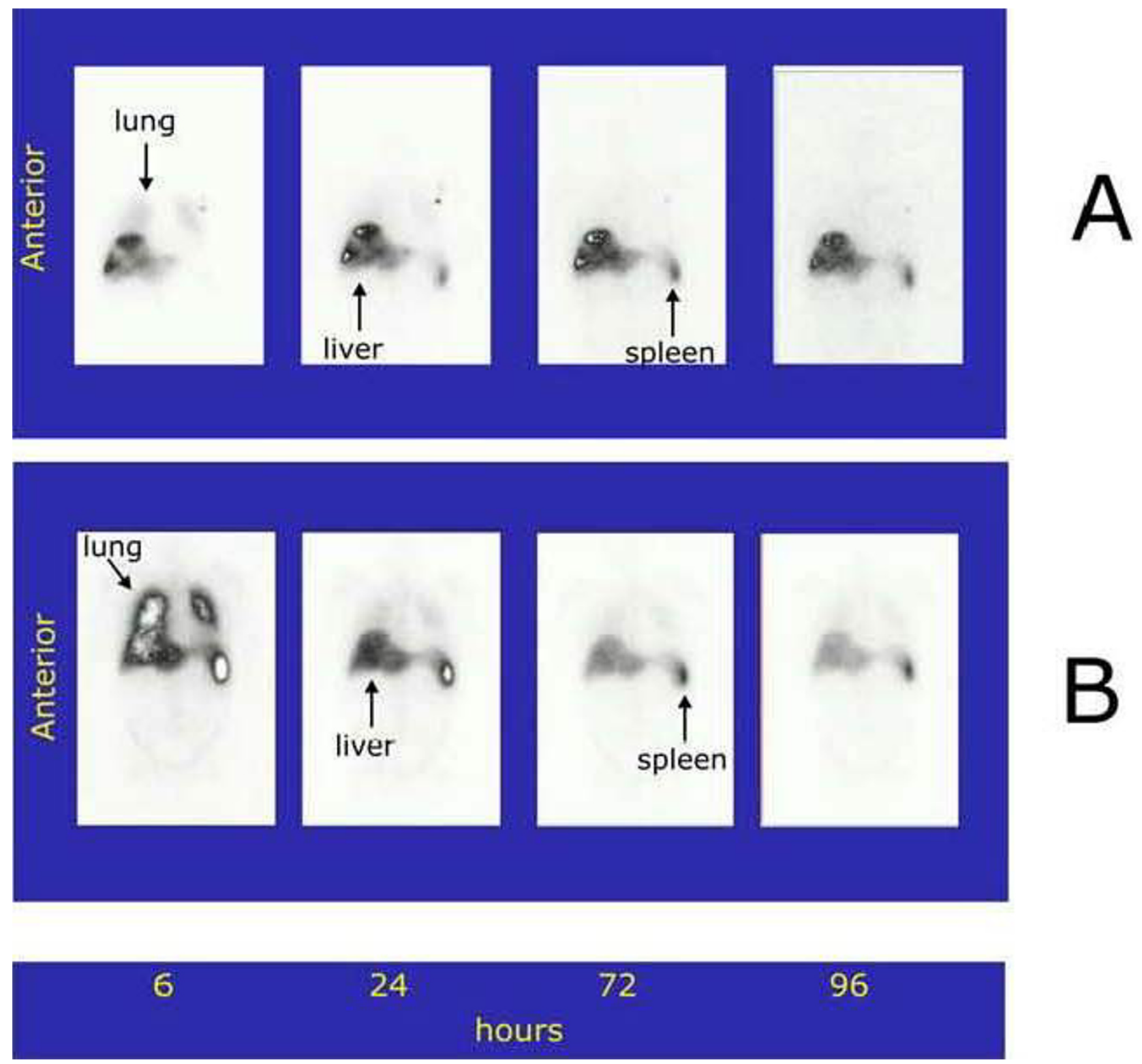

Figure 2

Representative planar whole-body images of organ migration of $"$ I'In-labeled A-NK after i.a. (A) and i.v. (B) injections (patient \#2). ${ }^{\prime \prime}$ In uptake was observed in the liver soon after the i.a. administration and persisted for up to $96 \mathrm{~h}$.

toxic functions of NK cells. Indeed, genes involved in NKcell homing, cytotoxicity and cytokine secretory functions are overexpressed in hepatic NK cells compared to blood NK cells [28], but their expression profile is similar to that of IL-2-activated blood NK cells. It is, therefore, very likely that the radioactivity detected in the metastatic areas of the liver is due to interactions between labeled A-NK cells and the tumor LSEC.
The ability of A-NK cells to penetrate the tumor tissue is relevant to their potential use as carriers of anti-tumor drugs and as direct killers of tumor cells. In experimental in vivo tumor models, NK cells are more frequently found to localize tumors which are also sensitive to NK cell killing in vitro [27]. Besides direct anti-tumor activities of NK cells, their localization in the liver tumor area would be important for the maturation of DCs, possibly through the production of IFN- $\gamma$ and other cytokines. 

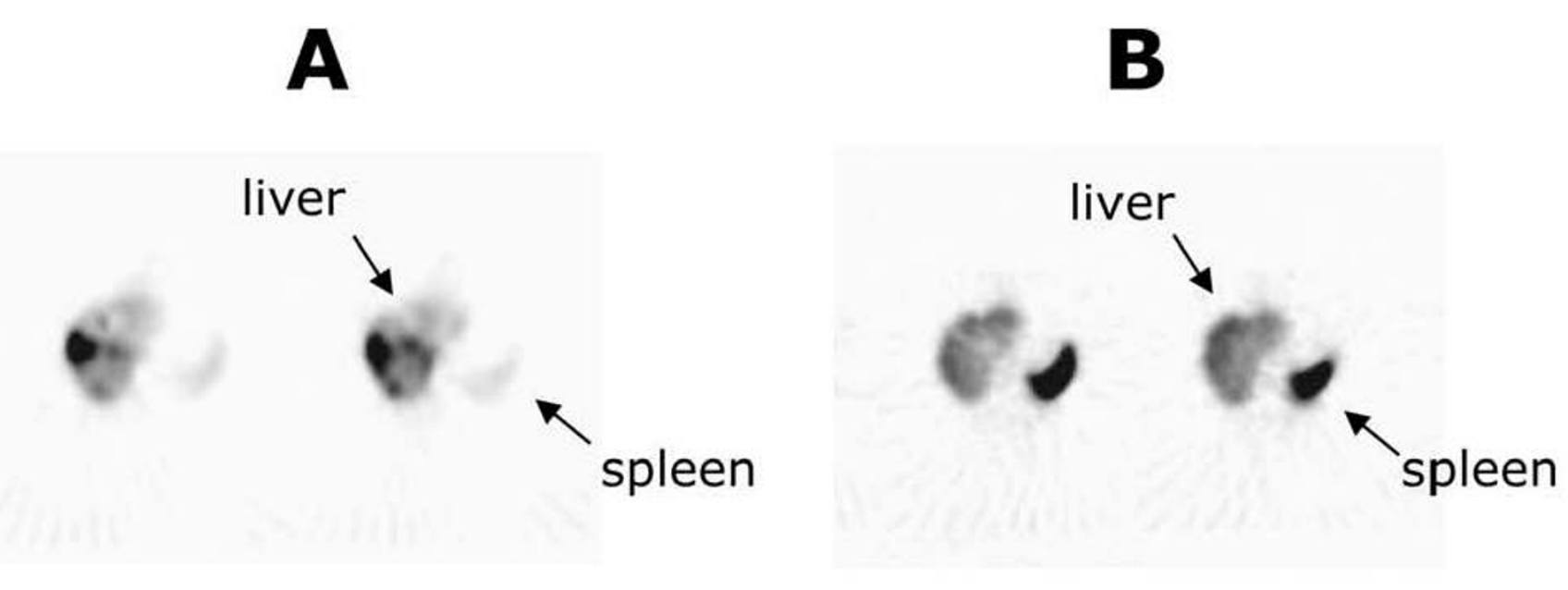

Figure 3

SPET images from patient \#I, 6 h after i.a. (A) or i.v. (B) injection of A-NK cells. Greater migratory activity of A-NK cells is observed in the liver after i.a. administration. Two consecutive axis sections are shown.

Two A-NK subsets predominated in our three patients after a fifteen-day expansion: $\mathrm{CD} 16+\mathrm{CD} 56{ }^{+} \mathrm{CD} 3+$ in patient \#1 and CD16+CD56+CD3- in patients \#2 and \#3. Adhesion to tissue cells expressing the relevant receptors is the main property of these cells, and it is conferred, among other molecules, by N-CAM, which is present on NK cells and a subpopulation of NKT cells $[31,32]$. NKT cells are the population best represented in the liver [33]. In our study, preferential ${ }^{111}$ In labeling of these A-NK subpopulations (both NK and NKT cells) in the metastatic compared to normal liver was observed.

We found a prompt localization of A-NK cells to the lung after i.v. injection, as also shown by other in vivo studies $[24,25,35]$. Transit of NK cells to the lung via the peripheral blood circulation is likely to play a surveillance role in vivo, since radiolabeled tumor cells injected i.v. are eradicated by NK cells before they enter the lung [27]. Radioactivity detected in our study is most probably attributable to cell-bound rather than to cell-free tracer for two reasons. First, the absence of excretion of radioactivity over the observation period (ref [25] and our data not shown) indicates extended survival of injected A-NK cells. Second, free tracer would not have been taken up by the tumor and was not taken up after i.v. administration (Fig. 5B bottom). The half-life of adoptively transferred NK cells is about 7-10 days [36]. This is particularly true in the permissive environment of liver sinusoids.

\section{Conclusion}

We have performed an imaging study of the biodistribution of ex vivo activated, adoptively-transferred autologous
A-NK cells and demonstrated their differential localization in normal hepatic parenchyma and liver metastases. The unique opportunity offered by this study of comparing different administration routes in the same patient, allowed unambiguous demonstration that A-NK cells localize to liver metastases only when injected locoregionally. This finding has important implications for the design of future immunotherapy protocols based on the principle that autologous A-NK cells adoptively transferred to the liver via the arterial route have preferential access and substantial accumulation to the tumor site.

\section{Abbreviations}

A-NK: adherent Natural Killer; i.v.: intravenously; i.a.: intraarterially; LSEC: liver sinusoidal endothelial cells; PME: phenylalanine methyil ester; cpm: counts per minute; SPET: single-photon emission-computed tomography.

\section{Authors' contributions}

LM had the idea for, coordinated and analysed experimental data, obtained funding and wrote the report.

AG contributed to protocol design, was in charge with the experiments and helped to draft the manuscript

SS and AM contributed to the protocol design.

IC and MAS contributed to protocol design, patients enrolment, follow up and clinical care. 


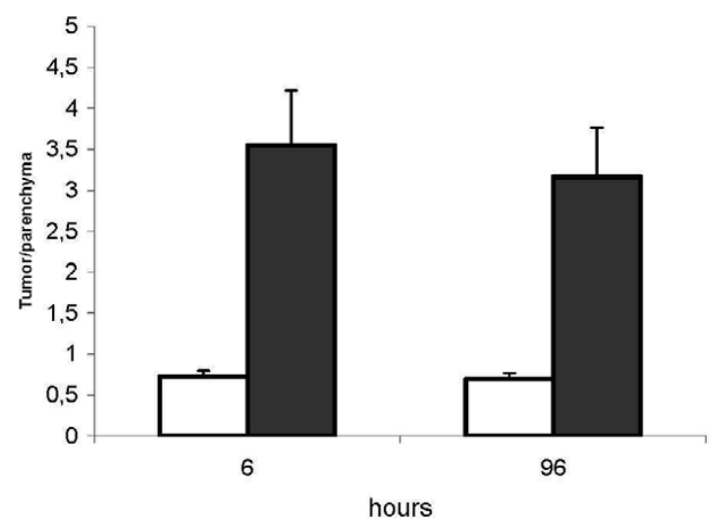

Figure 4

Normal parenchyma and tumor lesions. Patients were given $99 \mathrm{mTc}$ phytate before i.v. (open bars) or i.a. (full bars) IIIIn-Oxine labeled A-NK administration. The tumor/parenchyma labeling ratio ( $\mathrm{Y}$ axis) was calculated as the ratio between the $111 \mathrm{In}$ counts in metastatic (no ${ }^{99 \mathrm{mT}} \mathrm{c}$ phytate uptake) and normal ( $99 \mathrm{mT}$ c phytate uptake) SPET areas.

$\mathrm{GB}, \mathrm{MB}, \mathrm{CB}$ and GC were in charge for labelling and infusion of A-NK cells and imaging study.

AS performed phenotypical analysis of ex-vivo expanded A-NK cells.

$\mathrm{MM}$ contributed in the graphic elaboration of A-NK migration images.
TLW designed the A-NK protocols, critically analysed the results and revised the paper.

All authors read and approved the final manuscript.

\section{Acknowledgements}

We are in debt with the Blood Bank of the Molinette Hospital for expert collaboration. The work was supported by MIUR, Regione Piemonte

(Oncology project) and the CERMS/COES project funded by the "Compagnia di San Paolo/FIRMS". Informed consent was obtained from all patients.

\section{References}

I. Cooper MA, Fehniger TA, Caligiuri MA: The biology of human natural killer-cell subsets. Trends Immunol I99|, 22:633-640.

2. Soloski MJ: Recognition of tumor cells by the innate immune system. Curr Opin Immunol 200 I, I 3: I 54- I62.

3. Kuppen PJ, Gorter A, Hagenaars M, Jonges LE, Giezeman-Smits KM, Nagelkerke JF, Fleuren G, van de Velde CJH: Role of NK cells in adoptive immunotherapy of metastatic colorectal cancer in a syngeneic rat model. Immunol Rev 200I, I 84:236-243.

4. Dillman RO, Duma CM, Schiltz PM, DePriest C, Ellis RA, Okamoto K, Beutel LD, de Leon C, Chico S: Intracavitary placement of autologous lymphokine-activated killer (LAK) cells after resection of recurrent glioblastoma. J Immunother 2004, 27:398-404.

5. Ishikawa E, Tsuboi K, Saijo K, Harada H, Takano S, Nose T, Ohno T: Autologous natural killer cell therapy for human recurrent malignant glioma. Anticancer Res 2004, 24: I86I-I87|.

6. Klingemann HG, Martinson J: Ex vivo expansion of natural killer cells for clinical applications. Cytotherapy 2004, 6: I5-22.

7. Palumbo JS, Talmage KE, Massari JV, La Jeunesse CM, Flick MJ, Kombrinck KW, Jirousková $M$, Degen JL: Platelets and fibrinogen increase metastatic potential by impeding natural killermediated elimination of tumor cells. Blood 2005, 1 05: 178-185.

8. Fan Z, Yu P, Wang Y, Wang Y, Fu ML, Liu W, Sun Y, Fu YX: NK cell activation by LIGHT triggers tumor specific CD8+ $\mathrm{T}$ cell immunity to reject established tumors. Blood in press. 2005; Oct. 13

9. Gerosa F, Baldani-Guerra B, Nisii C, Marchesini V, Carra G, Trinchieri G: Reciprocal activating interaction between natural killer cells and dendritic cells. J Exp Med 2002, I95:327-333.

10. Moretta A: Natural killer cells and dendritic cells: rendezvous in abused tissues. Nat Rev Immunol 2002, 2:957-964.

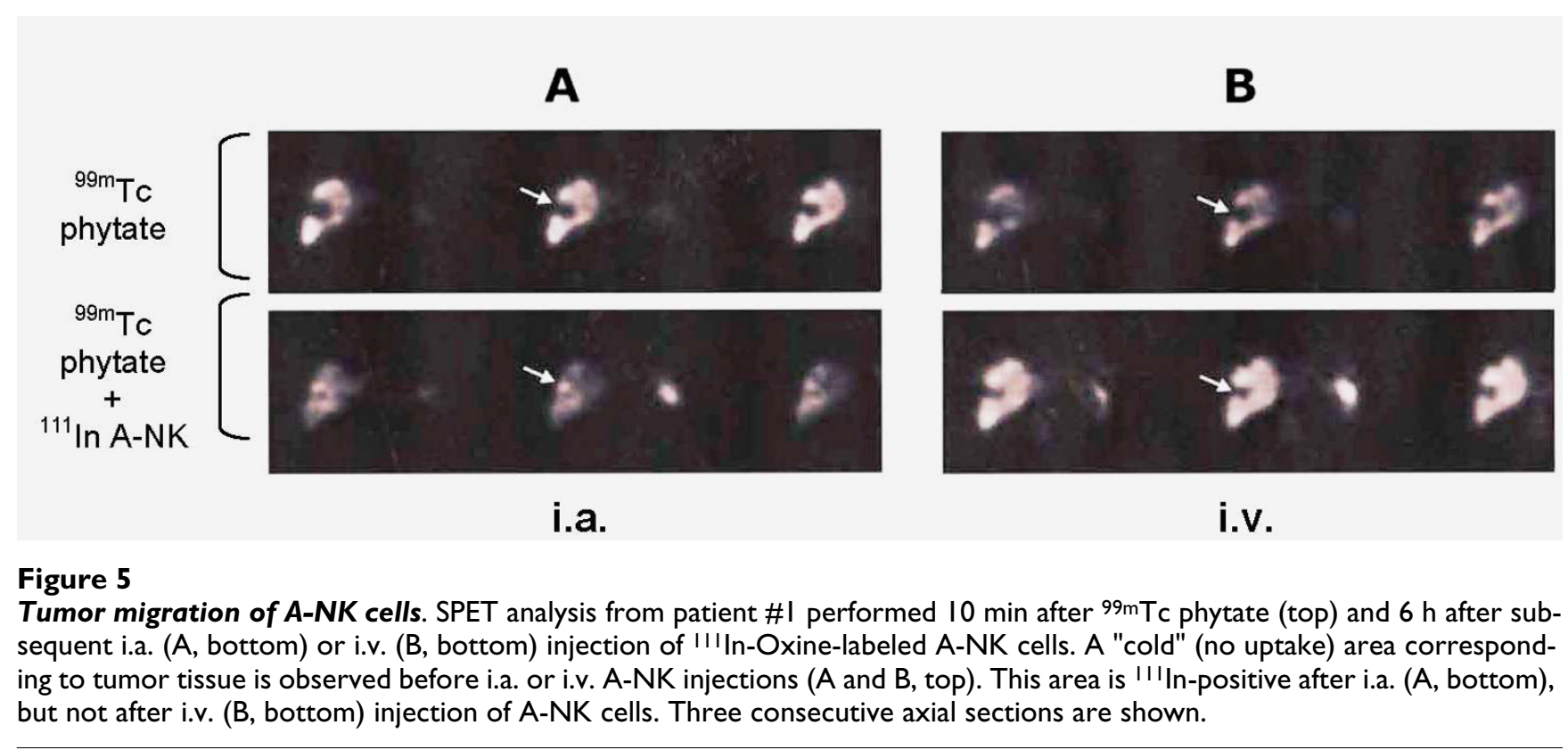


II. Piccioli D, Sbrana S, Melandri E, Valiante NM: Contact-dependent stimulation and inhibition of dendritic cells by natural killer cells. J Exp Med 2002, 195:335-34I.

12. Cooper MA, Fehniger TA, Fuchs A, Colonna M, Caligiuri MA: NK cells and DC interaction. Trends Immunol 2004, 25:47-52.

13. Fujii S, Liu K, Smith C, Bonito AJ, Steinman RM: The linkage of innate to adaptive immunity via maturing dendritic cells in vivo requires CD40 ligation in addition to antigen presentation and CD80/86 costimulation. J Exp Med 2004, 199:1607-1618.

14. Pan PY, Gu P, Li Q, Xu D, Weber K, Chen SH: Regulation of dendritic cell function by NK cells: mechanisms underlying the synergism in the combination therapy of IL-I 2 and 4-IBB activation. J Immunol 2004, I 72:4779-4789.

15. Galetto A, Buttiglieri S, Forno S, Moro F, Mussa A, Matera L: Drugand cell-mediated antitumor cytotoxicities modulate crosspresentation of tumor antigens by myeloid dendritic cells. Anticancer Drugs 2003, 14:833-843.

16. Mocikat R, Braumuller H, Gumy A, Egeter O, Ziegler H, Reusch U, Bubeck A, Louis J, Mailhammer R, Riethmüller G, Koszinowski U, Röcken M: Natural killer cells activated by MHC class low targets prime dendritic cells to induce protective CD8 T cell responses. Immunity 2003, 19:56I-569.

17. Dhodapkar MV, Steinman RM, Krasovskya J, Munza C, Bhardwaja N: Antigen-specific inhibition of effector $T$ cell function in humans after injection of immature dendritic cells. J Exp Med 200I, 193:233-238.

18. Schuler-Thurner B, Schultz ES, Berger TG, Weinlich G, Ebner S, Woerl P, Bender A, Feuerstein B, Fritsch PO, Romani N, Schuler G: Rapid induction of tumor-specific type I T helper cells in metastatic melanoma patients by vaccination with mature, cryopreserved, peptide-loaded monocyte-derived dendritic cells. J Exp Med 2002, 195: 1279-1288.

19. Lau $A H$, Thomson $A W$ : Dendritic cells and immune regulation in the liver. Gut 2003, 52:307-3।4.

20. Pillarisetty VG, Shah AB, Miller G, Bleier JI, DeMatteo RP: Liver dendritic cells are less immunogenic than spleen dendritic cells because of differences in subtype composition. J Immunol 2004, I72:1009-1117.

21. Zanon C, Grosso M, Clara R, Alabiso O, Chiappino I, Miraglia S, Martinetti R, Bortolini M, Rizzo M, Gazzera C: Combined regional and systemic chemotherapy by a mini-invasive approach for the treatment of colorectal liver metastases. Am J Clin Oncol 200I, 24:354-359.

22. Kobari M, Egawa S, Shibuya K, Sunamura M, Saitoh K, Matsuno S: Effect of intraportal adoptive immunotherapy on liver metastases after resection of pancreatic cancer. Br J Sur 2000 , 87:43-48.

23. Allavena P, Bianchi G, Paganin C, Giardina G, Mantovani A: Regulation of adhesion and transendothelial migration of natural killer cells. Nat Immunol 1996, I5:107-I I6.

24. Brand JM, Meller B, Von Hof K, Luhm J, Bahre M, Kirchner H, Frohn $C$ : Kinetics and organ distribution of allogeneic natural killer lymphocytes transfused into patients suffering from renal cell carcinoma. Stem Cells Dev 2004, | 3:307-3|4.

25. Morris MA, Ley K: Trafficking of natural killer cells. Curr Mol Med 2004, 4:43I-438.

26. Vujanovic NL, Yasumura S, Hirabayashi H, Lin WC, Watkins S, Herberman RB, Whiteside TL: Antitumor activity of subsets of human IL-2-activated natural killer cells in solid tissues. J Immunol 1995, 154:28I-289.

27. Yokoyama WM, Kim S, French AR: The dynamic life of natural killer cells. Ann Rev Immunol 2004, 22:405-429.

28. Vermijlen D, Seynaeve C, Luo D, Kruhoffer M, Eizirik DL, Orntoft TF, Wisse $\mathrm{E}$ : High-density oligonucleotide array analysis reveals extensive differences between freshly isolated blood and hepatic natural killer cells. Eur J Immunol 2004, 34:2529-2540.

29. Doherty DG, O'Farrelly C: Innate and adaptive lymphoid cells in the human liver. Immunol Rev 2000, 174:5-20.

30. Li Z, Lin H, Yang S, Diehl AM: Murine leptin deficiency alters Kupffer cell production of cytokines that regulate the innate immune system. Gatroenterology 2002, 1 23:1304-1310.

31. Nagler A, Lanier LL, Phillips J: Constitutive expression of highaffinity interleukin 2 receptors on human CDI6-negative natural killer cells in vivo. J Exp Med 1990, I7 I:1527-1533.
32. Li S, Xu J, Makarenkova VP, Tjandrawan T, Vakkila J, Reichert T, Gooding W, Lagenaur CF, Achim CL, Chambers WH, Herberman RB, Whiteside TL, Vujanovic NL: A novel epitope of N-CAM defines precursors of human adherent NK cells. J Leukoc Biol 2004, 76: II87-II99.

33. Seino K, Taniguchi M: Functional roles of NKT cell in the immune system. Front Biosci 2004, 9:577-587.

34. Franitza S, Grabovsky V, Wald O, Weiss I, Beider K, Dagan M, Darash-Yahana M, Nagler A, Brocke S, Galun E, Alon R, Peled A: Differential usage of VLA-4 and CXCR4 by CD3+CD56+ NKT cells and CD56+CDI6+ NK cells regulates their interaction with endothelial cells. Eur J Immunol 2004, 34:|333-|34|.

35. Kjaergaard J, Hokland ME, Agger R, Skovbo A, Nannmark U, Basse $\mathrm{PH}$ : Biodistribution and tumor localization of lymphokineactivated killer $\mathbf{T}$ cells following different routes of administration into tumor-bearing animals. Cancer Immunol Immunother 2000, 48:550-560.

36. Prlic M, Blazar BR, Farrar MA, Jameson SC: In vivo survival and homeostatic proliferation of natural killer cells. J Exp Med 2003, 197:967-976.

Publish with Bio Med Central and every scientist can read your work free of charge

"BioMed Central will be the most significant development for disseminating the results of biomedical research in our lifetime. "

Sir Paul Nurse, Cancer Research UK

Your research papers will be:

- available free of charge to the entire biomedical community

- peer reviewed and published immediately upon acceptance

- cited in PubMed and archived on PubMed Central

- yours - you keep the copyright
BioMedcentral 